\title{
Rebuilding Livelihood of the Rural and Peri-Urban Resettlers in Post-Involuntary Displacement of Saguling Dam Construction
}

\author{
Sunardi (Corresponding author) \\ Graduate Program of Environmental Studies Universitas Padjadjaran \\ J1. Sekeloa Selatan 1, Bandung 40132, West Java Province, Indonesia \\ E-mail: sunardi@unpad.ac.id
}

Miranti Ariyani

Research Unit for Clean Technology, Indonesian Institute of Sciences

Jl. Cisitu, Sangkuriang, Bandung 40135, West Java Province, Indonesia

E-mail: miranti.ariyani@gmail.com

\section{Rina Febriani}

Center for Environment and Sustainability Science, Universitas Padjadjaran

Jl. Sekeloa Selatan 1, Bandung 40132, West Java Province, Indonesia

E-mail: nafebri@gmail.com

Ghea Sakti Maharani

Center for Environment and Sustainability Science, Universitas Padjadjaran

Jl. Sekeloa Selatan 1, Bandung 40132, West Java Province, Indonesia

E-mail: gheamaharani@gmail.com

Regina Hoi Yee Fu

Faculty of Economics, Senshu University, Japan

E-mail: the0954@isc.senshu-u.ac.jp 


\title{
Ryo Fujikura
}

Faculty of Sustainability Studies, Hosei University, Japan

E-mail : Fujikura@hosei.ac.jp

Received: January 8, 2019

Accepted: January 24, 2019 Published: February 28, 2019

doi:10.5296/jad.v5i1.14421

URL: https://doi.org/10.5296/jad.v5i1.14421

\begin{abstract}
The construction of dams and reservoirs often comprises the displacement of not only communities but also the livelihood of the communities itself. This study aims to explore the effects of Saguling Dam construction on the livelihood re-establishment of the displaced people, by paying more attention on the sociographic localities of the new settlement, i.e. the rural and peri-urban areas. A survey was conducted on two groups of resettlers equiped with structured questionnaire. The results indicated that the project has imposed hardship on the displaced people in the process of livelihood re-establishment. Beside changes and lost of occupation, lost of resources, and insufficient cash compensation, sociographic localities of the two groups determined their social capital, which was also vital to their livelihood reconstruction.
\end{abstract}

Keywords: Saguling Dam project; resettlement; livelihood; sociographic localities; rural and peri-urban

\section{Introduction}

Based on World Energy Council (2017), hydropower is the leading renewable source for electricity generation globally which supplies $71 \%$ of all renewable electricity. With regard to the hydropower generated through the release of stored water structured in reservoir, building dams turns out to be vital and cannot be avoided. Dams become one of the most important symbols of modernization (Kaika, 2006) and industrialization (Wang et al., 2013), especially for those who categorized as developing countries. The construction of dams and reservoirs often comprises the displacement of not only communities but also the livelihood of the communities itself. The deterioration of living standards caused by the project is a result of the loss of productive assets and the disruption of the social network existed within communities (Cernea \& Schmidt-Soltau, 2006; Webber \& Mc Donald, 2004). However, as there is really no other choice, the main issue facing the developing countries is not whether large dams have an important role to play in the coming decades, but rather how best we can continue to improve their overall effectiveness for human welfare, poverty eradication and environment preservation (Biswas \& Tortajada, 2001).

In the case of Saguling project, Department of Mines and Energy (1985) argued that there will be six benefits gained from this dam, i.e.: (a) to increase the power and reliability of the 
electricity system by installing $700 \mathrm{MW}$ of generating capacity and producing 2,156 GWH of electric energy per year; (b) to conserve 647,000 tons of oil per year; (c) to increase the reliability of water in a reservoir in the downstream reach for irrigation and drinking water; (d) to promote industrial and economic development; (e) to facilitate fisheries and tourism; and (f) to facilitate new employment. However, inundation of Saguling area has forced large number of people to move to new areas where they had to strive for a new livelihood. About 10,664 families were affected both directly and indirectly by this project. Approximately 3,038 families moved because their territories were submerged, and other 7,626 families who had land and sources of income in the inundated area (PLN, 1989) were affected. Nakayama et al. (1999) mentioned that at least half of the resettlers failed to re-establish their living to the standard they enjoyed previously.

Negative consequences caused by involuntary resettlement are common with the conditions that lead to socio-economic hardship (World Bank, 2004). In the case of Saguling, previous studies have addressed discrepancies following the implementation of the Saguling Project. Nakayama (1998) identified five aspects which have been improperly dealt with either in the EIA study or during the implementation of the project. These aspects were (a) collapse of the community; (b) improperly conveyed information for resettlers; (c) distrust among residents; (d) employment by construction project; and (e) compensation for resettlers. Other researches have emphasized the household or livelihood of resettlers affected by Saguling dam construction. For example, Fujikura and Nakayama (2012) analysed long term impacts of dam projects by comparing Saguling case with other similar projects in Japan, Laos, Sri Langka, Turkey and other reservoir cases in Indonesia. Sunardi et al. (2013) have also reported about the livelihood status of resettlers after 25 years of inundation.

While existing studies have contributed to the understanding of the impact of Saguling project on the resettlers in general, the current paper discusses the long-term impacts of the construction on the displaced people by paying more attention to sociographic differences between the settlements they selected. This paper aims to explore (1) if the process of the livelihood re-establishment of the Saguling resettlers run successfully after a long period, and (2) if the sociographic localities of the new settlement, i.e. rural and peri-urban areas, have visible effects on the livelihood re-establishment. We expect to have insight on whether localities may relate to social capital, and hence affect the livelihood of the resettlers.

\section{Methods}

\subsection{Research Sites}

This study was conducted to find out the current situation and condition of the resettlers who moved to the vicinity of Saguling which was characterized by rural area, and those who moved to the peri-urban area. The respondents who lived in areas close to Saguling reservoir were mostly in Bongas and Sarinagen Villages (part of Bandung Barat Regency, West Java). Bongas lied in the southern section of Saguling lake, whereas Sarinagen was in the nothern part. The respondents who moved to the peri-urban area lived in Batujajar (part of Bandung Barat Regency) and Rajamandala sub-district (part of Cianjur Regency), the areas which were $\pm 15 \mathrm{~km}$ away from Saguling reservoir (see Figure 1). 


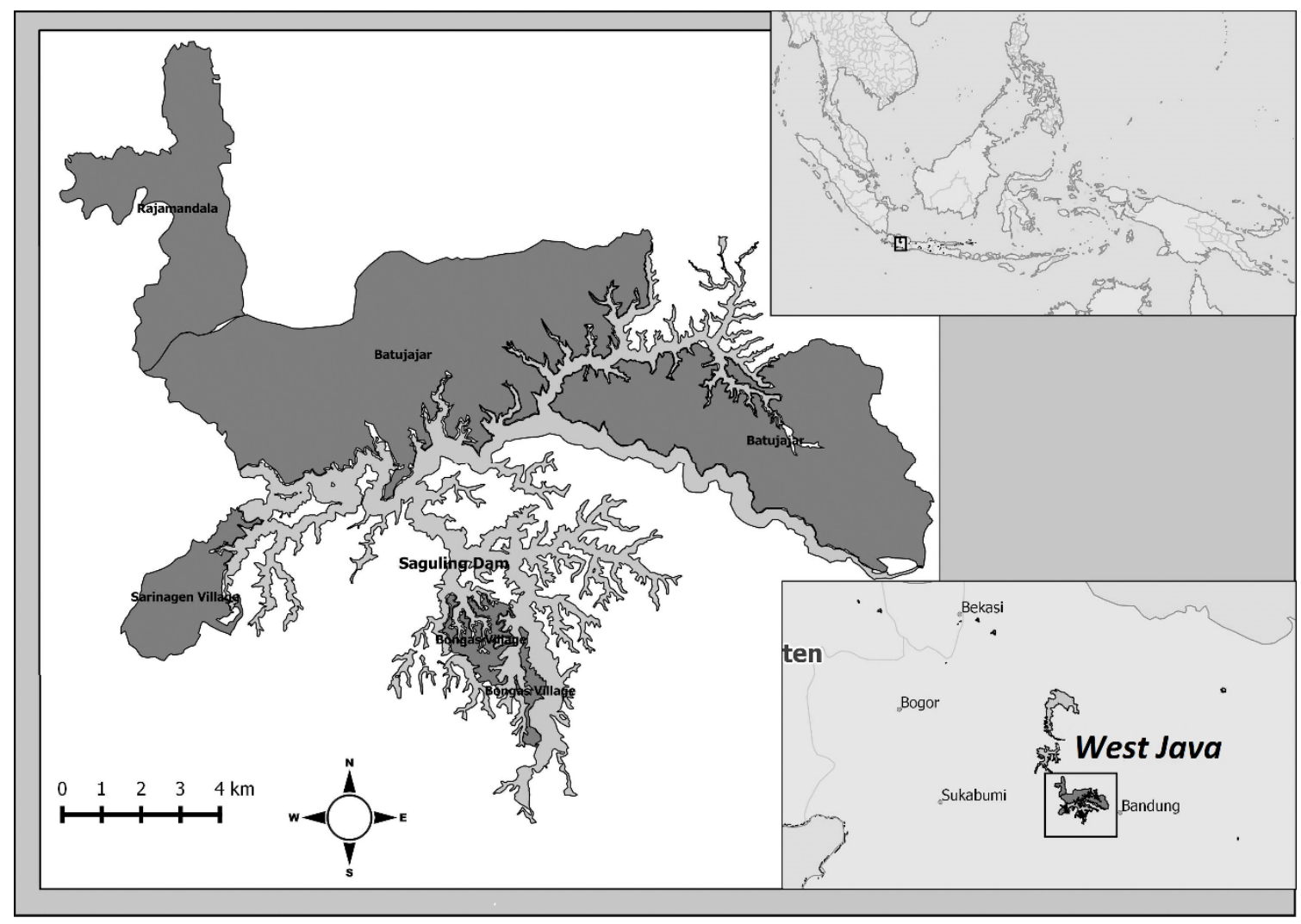

Figure1. Location of the study: Sarinagen and Bongas Villages, and Rajamandala and Batujajar Sub-districts

\subsection{Data Collection and Analysis}

Descriptive approach was used in this study to compare the socio-economic condition between the resettlers who live in the vicinity of Saguling and peri-urban area. The study was conducted in 2016 and 2018 by interviewing several heads of the families, which consisted of the first and second generation. Direct observation was also performed to cross-check the data collected from the respondents. Literature review was done to offer remarkable insight into this study. The first generation were the resettlers who were the head of households during the relocation in 1987, or who were married. Whereas, the second generation were the children who were not married yet at the time of relocation. The number of respondents (51) from the vicinity of the reservoir were sampled purposefully, while the respondents (10) from peri-urban area were traced by snow-ball technique. In total, the respondents were 61 persons consisted of 48 from the first generation and 13 from the second generation. The family members were also traced through the respondents, and their occupation, education, and income were also documented. Including the respondents, the total family members were 371 persons containing the first and second generation including the wifes or spouses of the respondents. A number of 331 members was in the productive age, while the remaining ones (40 persons) were still enrolling education in the time of data collection.

To explore the socio-economic status and perceptions of the resettlers, in the first phase, all 
61 heads of the family were interviewed using structured questionnaire in 2016. The quantitative data were grouped into parameters of socio-economic state, perceptions or behaviors related to compensation usage, and then tabulated to have a comparative description among the indicators. For the purpose, the data analysis was limited to second generation level. In particular for income data, the values obtained from the survey were converted using GDP deflator before interpretation. Refering to the World Bank, the GDP deflator for Indonesia was 4,6 for the time before relocation, and 131,5 for that after relocation. The conversion using GDP deflator was meant to make the income more realistic by taking into account the deflation and inflation. In addition to that, the qualitative data collected from in depth interview were used to explain or clarify the relevant aspects from the quantitative data.

In the second phase, an interview was again conducted on the resettlers to explore whether social capital has affected their livelihood re-establishment in 2018. Another structured questionnaire was used to interview the heads of household, eighteen from the rural area and eleven from the peri-urban area. The questions emphasized on exploration of social capital measures perceived by the resettlers, such as social bond, social bridge, and social link (Ager $\&$ Strang, 2008). Comparative description was also done to find out the distinctions in social aspects between the groups.

\section{Results and Discussion}

\subsection{Socio-Economic State of the Resettlers Before and After Relocation}

According to Wilmsen and Weber (2015), income is the main indicator used by organisations such as the World Bank to assess resettlement activities. Our study on income (adjusted to 2016 price) of the resettlers revealed that the average annual income of individual head of family was about 9,783 USD before the relocation, while by the present time, their income has dropped to 7,295 USD. Similarly, the average annual income at family level has decreased from 10,956 USD before relocation, to 10,057 USD at the present time (see Table 1). Our data suggested that the economic condition of resettlers have not improved in the context of income, decades after relocation.

Table 1. Average annual income (2016 price) of the resettlers before relocation and at present

\begin{tabular}{lll}
\hline Type of Income & Before (In USD) $^{1}$ & Present (in USD) $^{2}$ \\
\hline Head of Family & 9,783 & 7,295 \\
Family income & 10,956 & 10,057 \\
\hline
\end{tabular}

${ }^{1}$ Exchange rate of at the time of relocation (1985) was 1,025 IDR to 1 USD.

${ }^{2}$ Exchange rate in 2016 was 13,330 IDR to 1 USD.

From sociographic rural and peri-urban perspective, however, the level of income differs between the two groups of resettlers at present time. On average, the resettlers who live in peri-urban area have lower annual income compared with those who live surrounding the 


\section{Ml Macrothink}

reservoir. The current income of the head of family in peri-urban area is 5,813 USD, and that of family is 12,707 USD annually. Meanwhile, the resettlers who live surrounding the reservoir earn 7,643 USD annually for each head of family, and 9,619 USD for family level. The heads of family in peri-urban area indeed earn lower income, however, those in family level are significantly higher. The number of family members also determine the level of enjoyment obtained from the income. Our data show that the average number of family members in peri-urban households are fewer, 6 persons consists of parents, children, and grandchildren, while family members in Saguling area are 6.5 person on average. Therefore, when we look at the income per capita, the resettlers living in peri-urban area will share higher amount of money, hence they will be more prosperous compared with those living in the vicinity of the reservoir.

It was obvious that land ownership has changed drastically due to involuntary resettlement. Our survey has revealed that the total land owned by the resettlers before relocation and at present (Table 2). The paddy field, dry field and domestic farmland have reduced substantially thirty years after the relocation. Each type of the land use has reduced by more than $70 \%$ compared with the previous size, and the highest degradation happened in farmland (95.15\%). Interestingly, there has been a remarkable increase in the total width of fish pond at present. Nevertheless, the productivity of fish pond itself is still unknown. Based on the data we inferred that majority of the resettlers have quitted farming and changed their occupation as we found only few farmers remained.

Table 2. Cumulative land owned by the resettlers

\begin{tabular}{lll}
\hline Land use type & $\begin{array}{l}\text { Before relocation } \\
\left(\mathrm{m}^{2}\right)\end{array}$ & $\begin{array}{l}\text { Present condition } \\
\left(\mathrm{m}^{2}\right)\end{array}$ \\
\hline Paddy field & $2,845,900$ & 137,900 \\
Dry field & 55,275 & 12,075 \\
Domestic farmland & 203,039 & 31,527 \\
Fish pond & 200 & 34,100 \\
\hline
\end{tabular}

Involuntary relocation caused by the construction of Saguling dam has posed negative impacts on the villagers. In the new environment, adaptation was not always easy for resettlers; occupation was one of the most seriously affected living aspects following the involuntary relocation. For those who were displaced at the time of dam construction, they were uprooted from their jobs and their lives. Our data indicated that there were not many job options available for them. Most of the villagers lost their business as an enterpreneur, and $12.99 \%$ (10 persons) of them became unemployed (Table 3). The predominant jobs of the first generation before the relocation were reseller (i.e. 18 out of 95) and farming (15 out of 95) both as self employed farmer and farm labour. IOE (1985a) revealed that most of the resettlers before relocation were farmer; about 4,713 ha of land at Saguling area used to be 


\section{Macrothink

agricultural land consisted of paddy and dry field. IOE (1985b) also recognised that about 109 farming families have become poorer after the resettlement because they were unable to grow enough crops on the new land. The amount of cash compensation was not sufficient for them to buy farm land of the same size that they owned previously. Several studies have reported insufficiency of cash compensation that caused failure to resettlers when reconstructing their lives (Cernea, 2008; Sisinggih et al., 2013; Yoshida et al., 2013; Siciliano et al., 2015). Cernea (2008) argues that compensation is presumably the basic remedy for eminent domain dispossession and forcible displacement. However, money alone as monetary compensation may not be sufficient to offset non-monetary losses, in particular the social capital that constitutes an important part of agrarian livelihood (Tilt \& Gerkey, 2016).

Our study showed that the number of farmers has decreased remarkably at the present time to $2.60 \%$ and $3.90 \%$ from $6.32 \%$ and $9.47 \%$ respectively for self employed farmers and farm labourers. Nakayama et al. (1999) noticed that the difficulties in obtaining farmland surrounding Saguling made few of the resettlers oblige to change their occupation from agriculture into non-agriculture sectors.

Interestingly, the types of occupation among the second generation vary markedly; this contributes to higher family income at the present time. The number of second generation who work at private sectors and public offices as civil servant and teacher have increased to $4.33 \%, 7.48 \%$ and $5.12 \%$ respectively, much higher compared with that of the first generation. A high number of the second generation (42 out of 254) was absorbed in the sector of construction labour, while $2.76 \%$ of resettlers ( 7 persons) work as Indonesian labor at abroad, a new job opportunity that was not available in the time of relocation. In addition, the number of unemployees among the second generation has decreased significantly compared with that among the first generation, i.e. from $12.99 \%$ to $4.33 \%$. We believe that greater access of the second generation to various occupations is strongly related to the improvement of their education. 
Table 3. Occupation of the resettler' family members before and after resettlement

\begin{tabular}{|c|c|c|c|c|}
\hline \multirow[b]{2}{*}{ Type of occupation } & \multirow[b]{2}{*}{ Detail of occupation } & \multicolumn{3}{|c|}{ No. of family members } \\
\hline & & $\begin{array}{l}\text { Before } \\
\text { resettlement }\end{array}$ & $\begin{array}{l}\text { After } \\
\text { resettlement (1st } \\
\text { generation) }\end{array}$ & $\begin{array}{l}\text { After } \\
\text { resettlement } \\
\text { (2nd } \\
\text { Generation) }\end{array}$ \\
\hline Farmer & Self Employed Farmer & 6 & 2 & 10 \\
\hline \multirow{3}{*}{ Employee } & Civil Servant & 3 & 1 & 11 \\
\hline & Private Sector Employee & 3 & 2 & 19 \\
\hline & Public Offices & 1 & 0 & 0 \\
\hline \multirow{3}{*}{ Labourer } & Farm Labor & 9 & 3 & 1 \\
\hline & Construction Labour & 4 & 5 & 42 \\
\hline & Mining Labour & 0 & 0 & 1 \\
\hline \multirow{2}{*}{ Aquatic cage farmer } & Aquatic cage farmer & 0 & 2 & 3 \\
\hline & Aquatic cage labour & 0 & 0 & 1 \\
\hline Reseller/business & Reseller/business & 18 & 2 & 31 \\
\hline Convection/Tailor & Convection/Tailor & 5 & 4 & 3 \\
\hline Preacher & Preacher & 2 & 3 & 3 \\
\hline Teacher & Teacher & 1 & 1 & 13 \\
\hline Driver & Driver & 1 & 1 & 3 \\
\hline $\begin{array}{l}\text { Indonesian Worker } \\
\text { Abroad }\end{array}$ & $\begin{array}{l}\text { Indonesian } \\
\text { Abroad }\end{array}$ & 0 & 0 & 7 \\
\hline Housemaid & Housemaid & 1 & 0 & 1 \\
\hline Housewife & Housewife & 41 & 41 & 81 \\
\hline Unemployee & Unemployee & 0 & 10 & 11 \\
\hline Unknown & Unknown & 0 & 0 & 13 \\
\hline Total & & 95 & 77 & 254 \\
\hline
\end{tabular}

From sociographic localities, the data indicate that the types of job owned by those who live close to Saguling reservoir are more diverse in the present time (Table 4). We believe that the higher diversity or the types of occupation contribute to the higher income of the resettlers in the area close to reservoir. Among the family of displaced people, many of them still engage in reseller/business, aquaculture, and other prospective jobs. Wilmsen (2016) revealed that having a job as enterprise at the Three Gorges Dam resettlement area increased the estimated income growth by 81 percentage points. However, the people who live in vicinity of the reservoir prefer to be a businessman/reseller than to be a fish farmer. Deteriorating water quality and large quantities of capital is one of the reasons that makes aquaculture sector less attractive to the resettlers around Saguling. Gunawan (1992) showed that only a very limited 
number of resettlers could spare large amount of money as a capital to initiate aquaculture after resettlement. In addition, Sunardi et al. (2013) revealed that poor water quality due to continuous heavy pollution in Citarum river became the main factor for drastical decrease in productivity of aquaculture.

Table 4. The present occupation of the resettler' family members in the vicinity of Saguling and peri-urban area

\begin{tabular}{|c|c|c|c|}
\hline \multirow{2}{*}{ Type of occupation } & \multirow{2}{*}{ Detail of occupation } & \multicolumn{2}{|c|}{ No. of family members } \\
\hline & & Vicinity Saguling & Peri-urban \\
\hline Farmer & Self Employed Farmer & 16 & 0 \\
\hline \multirow{2}{*}{ Employee } & Civil Servant & 12 & 1 \\
\hline & Private Sector Employee & 14 & 5 \\
\hline \multirow{3}{*}{ Labourer } & Farm Labor & 4 & 0 \\
\hline & Construction Labour & 42 & 2 \\
\hline & Mining Labour & 1 & 0 \\
\hline \multirow{2}{*}{ Aquatic cage farmer } & Aquatic cage farmer & 3 & 0 \\
\hline & Aquatic cage labour & 1 & 0 \\
\hline Reseller/business & Reseller/business & 39 & 3 \\
\hline Convection/Tailor & Convection/Tailor & 0 & 3 \\
\hline Preacher & Preacher & 6 & 0 \\
\hline Teacher & Teacher & 14 & 0 \\
\hline Driver & Driver & 4 & 0 \\
\hline Indonesian Worker Abroad & Indonesian Worker Abroad & 6 & 1 \\
\hline Housemaid & Housemaid & 1 & 0 \\
\hline Housewife & Housewife & 112 & 10 \\
\hline Unemployee & Unemployee & 17 & 0 \\
\hline Freelancer & Freelancer & 0 & 1 \\
\hline Unknown & Unknown & 0 & 13 \\
\hline Total & & 292 & 39 \\
\hline
\end{tabular}

In regard to the education, the displaced people enjoy a better education. The the number of second generation who have completed senior high school education was significantly greater (Table 5). We find that 23 members $(8.43 \%)$ of the second generation are enrolling in undergraduate and master study in the university. This pattern is similar to the education level gained by Nam Mang 3 project resettlers in Laos (Sayatham \& Suhardiman, 2015). In the case of Saguling project, no uneducated persons are found among the second generation. The access to the school facilities at new settlement area is an important factor in enhancing 


\section{Macrothink

education. It is clear that better school facilities have motivated the resettlers to send their children to schools, even though few of them complain that there is a further distance between where they live and the schools. We observe that the parents have greater awareness of the importance of better education, and thus encourage their children to get the highest level of education possible.

We believe that the improved education has shifted the socio-economic status of the resettlers through greater access to occupations; it is proven particularly in the case of the second generation in Saguling project. Wilmsen (2016) revealed that the level of education had a positive and significant effect on estimated income growth of the resettlers at the Three Gorges Dam in China.

Table 5. The education Profile of the resettler' family members of first and second generation

\begin{tabular}{lll}
\hline \multirow{2}{*}{ Education Background } & No. of family members & \\
\cline { 2 - 3 } & First Generation & Second Generation \\
\hline Uneducated & 26 & 0 \\
\hline Elementary School & 79 & 138 \\
\hline Junior High School & 3 & 45 \\
\hline Senior High School & 0 & 54 \\
\hline Undergraduate & 2 & 21 \\
\hline Postgraduate & 0 & 1 \\
\hline Unknown & 0 & 2 \\
\hline Total & 110 & 261 \\
\hline
\end{tabular}

The variety of jobs owned by the resettlers around the reservoir are allegedly related to their educational background. The data show that the proportion of people around the reservoir who have higher level of education such as senior high school, undergraduate and postgraduate is greater than those in peri-urban (Table 6). Decreasing farmland and deterioration of reservoir water quality are considered as the triggering factor that motivate the resettlers to encourage their children to have a higher education level. They believe that higher level of education brings wider option of job opportunity, and hence better livelihood. Kura et al (2017) argued that variety of educational background may contribute to income generating activities to allow resettlers adopting strategies that do not overly depend on single source of income. 
Table 6. Education level of second generation in both vicinity of Saguling and peri-urban area

\begin{tabular}{lll}
\hline \multirow{2}{*}{ Education Background } & No. of members & \\
\cline { 2 - 3 } & Vicinity Saguling & Peri-urban \\
\hline Elementary School & 123 & 15 \\
\hline Junior High School & 31 & 14 \\
\hline Senior High School & 47 & 7 \\
\hline Undergraduate & 21 & 0 \\
\hline Postgraduate & 1 & 0 \\
\hline Unknown & 2 & 0 \\
\hline Total & 225 & 36 \\
\hline
\end{tabular}

\subsection{Way to Spend Compensation Cash}

According to Hang Bui et al. (2013), the ability of resettler to rehabilitate their livelihood after involuntary resettlement is strongly related to their livelihood assets and available livelihood strategies. The resettlers most probably prefered to accept "land to land" as compensation. However, that was not the case as such scheme was not provided in the area of West Java; land was provided only in the transmigration area which was outside of Java Island. Only $3.9 \%$ of the displaced people chose the transmigration scheme, while most of them moved to areas close to the reservoir (Suwartapradja et al., 1985). Our survey indicated that most of the resettlers $(65.57 \%)$ prefered to receive cash compensation equal to fair price of the submerged land; few of them $(27.87 \%)$ remained to choose equivalent land size for compensation. We found that they expected to receive the compensation cash directly from the board of the project, not through intermediaries. Some of the resettlers were victims of fraud by irresponsible persons. As regarded by Singer and Watanabe (2014), many infrastructure projects in developing countries have caused residents suffer from asymmetric access to project information, weak financial clout and inadequate representation in implementation bodies. In Saguling resettlement case, the resettlers complained that dissemination of information regarding compensation was rather unclear and mazy to many of residents. Different information circulated within community and was perceived in different ways by the affected people. Nakayama (1998) noticed that very limited counter-measures have been put during the implementation of the project to avoid such frauds.

The above situation might have encouraged the resettlers to use the compensation cash wisely. We found that majority of the resettlers spent their money for primary needs such as house, education and daily necessities like food (Table 7); few of them spent their money for secondary and tertiary needs, such as purchasing vehicles, electronic appliances, and religious pilgrimage. Individual factors such as household assets, resources and strategies would presumably affect income and resettler livelihood (Wilmsen, 2016). Adger et al. (2009) and Osbahr et al. (2010) stated that when faced with risks and shocks, individuals and 


\section{Ml Macrothink}

Journal of Asian Development

ISSN 2377-9594

2019, Vol. 5, No. 1

communities manage their resources and livelihoods, prioritizing between elements of the production, consumption, and ecological systems in which they operate. Our finding was in contrast with the statement of World Bank (2004) and Development Assistance Committee (1992) which pointed out that cash compensation could cause the risk of impoverishment, which was simply due to the probability of resettlers to use the money for purposes which were not related to life rehabilitation.

Table 7. Way to spend compensation money by the Saguling resettlers

\begin{tabular}{ll}
\hline Purpose & No. of respondents \\
\hline Purchase house and land related house establishment & 27 \\
\hline Building house & 4 \\
\hline Purchase farm land & 4 \\
\hline Food consumption & 6 \\
\hline Education & 7 \\
\hline Purchase vehicles & 1 \\
\hline Purchase electronic appliances & 1 \\
\hline Saving & 2 \\
\hline Pilgrimage & 3 \\
\hline Others & 6 \\
\hline Total & 61 \\
\hline
\end{tabular}

\subsection{Satisfaction With Present Livelihood}

After about thirty years of the relocation, our study indicated that $42.62 \%$ ( 26 persons) of the resettlers, regardless their settlement area, are satisfied with their current condition, while about $44.26 \%$ ( 25 persons) of them perceive otherwise. Investigation on satisfaction of the former residents is necessary in order to understand whether the implementation of this project is successful (Sisinggih et al., 2013). If almost half of the affected people feel unhappy, we may consider that the resttlement program is not fully successful. If we divide the data of satisfaction into two groups, of resettlers in the vicinity and in peri-urban area, the result then differed.

Approximately $49.02 \%$ of those from vicinity of the reservoir are not satisfied with the current condition as they feel that the level of the welfare decreased markedly. Meanwhile, about $50 \%$ of the resettlers who live in the peri-urban area mention that easier access and better facilities are factors that contributed to their satisfaction (Table 8). Similarly, better transporation acess and new infrastructures became the main factors of resettlers' satisfaction in Bili-Bili Dam case in South Sulawesi (Agnes et al., 2009) and in Cambodia (Siciliano et al., 2015). 


\section{Macrothink}

Table 8. Satisfaction between the resettlers

\begin{tabular}{lll}
\hline \multirow{2}{*}{ Category of Satisfaction } & No. of respondents & \\
\cline { 2 - 3 } & Vicinity & Peri-urban \\
\hline Not Satisfied & 25 & - \\
\hline Satisfied with money compensation & 2 & - \\
\hline Satisfied with better income & 5 & 3 \\
\hline Satisfied with better access & 5 & 2 \\
\hline Satisfied with better infrastructure & 7 & - \\
\hline Satisfied with floating net cage & 2 & - \\
\hline Others & 3 & 3 \\
\hline Did not answer & 2 & 10 \\
\hline Total & 51 & \\
\hline
\end{tabular}

Nakayama et al. (1999) recognised that although most of the compensation money was spent to purchase land (paddy field, dry land, or home garden), nearly half of the resettlers were found to have failed in re-establishing their living to the standard they enjoyed previously. This condition may become the reason why dissatisfaction among the resettlers remain high until present.

\subsection{Social Aspects of the Rural and Peri-Urban Resettlers}

Social integration and adaptability play an important role in the success of rebuilding livelihood of the resettlers. Studies have indicated the relation of social capital with the state of livelihood, health, education, employment, and food security in involuntary displacement (Quetulio-Navara et al., 2013). Refering to "bonding" social capital, the resettlers of both rural and peri-urban areas differ in their perception and feeling. For majority of those who live in the rural area surrounding the reservoir, they feel no difference in culture, habits, religion and major occupation, while those in the urban area do feel the differences. Eight out of eleven resettlers perceive that in their new urban environment people are lack of mutual cooperation or more individualistic (Table 9). A weaker social bond between resettlers and the host community has affected them in re-establishing their occupation, income and livelihood in general. 


\section{Macrothink}

Table 9. Differences in Custom perceived by the resettlers

\begin{tabular}{lll}
\hline \multirow{2}{*}{ Kinds of difference } & No.of respondents & \\
\cline { 2 - 3 } & Vicinity of reservoir & Peri-urban area \\
\hline No difference & 15 & 2 \\
\hline Religious practice & 1 & 0 \\
\hline Habit/Culture & 0 & 8 \\
\hline Major occupation & 2 & 0 \\
\hline Not remember & 0 & 1 \\
\hline Total respondents & 18 & 11 \\
\hline
\end{tabular}

In the context of social bridge, results indicate that there is no particular issue for both groups in the social integration process. The resettlers from both sites are welcomed by the host community (Table 10a), and they are able to involve in social meetings and events easily either through invitation or voluntary attendance (Table 10b). Seven out of eighteen resettlers in rural area stated that there was no invitation for social meetings and events but it did not mean that there was an issue of social integration in the rural environment.

Table 10a. The host community acceptance perceived by the resettlers

\begin{tabular}{lll}
\hline \multirow{2}{*}{ Acceptance } & No. of respondents & Peri-urban area \\
\cline { 2 - 3 } & Vicinity of reservoir & 10 \\
\hline Welcome & 18 & 0 \\
\hline Not welcome & 0 & 1 \\
\hline Not remember & 0 & 11 \\
\hline Total respondents & 18 & \\
\hline
\end{tabular}

Table 10b. Involvement of the resettlers in social meetings and events

\begin{tabular}{lll}
\hline \multirow{2}{*}{ Way to Involve } & No.of respondents & Peri-urban area \\
\cline { 2 - 3 } & Vicinity of reservoir & 4 \\
\hline Invited & 8 & 7 \\
\hline Voluntarily & 3 & 0 \\
\hline No invitation & 7 & 11 \\
\hline Total respondents & 18 &
\end{tabular}

The attitude and service of government officers provide a useful support for reconstruction of livelihood. Majority of the resettlers perceive that the officers have forwarded a good attitude 
to them (Table 11a). Only few of those who live in rural area close to the reservoir feel that government officers are less friendly and helpful. The government officers have provided wide range of services and assistance, such as arrangement of civil documents and residential cards, supports for economic activities, etc (Table 11b). Linking social capital, as defined by Woolcock and Narayan (2000), is the vertical dimension that 'reaches out' or 'scales up' people's ties to resources, ideas, and information which generate a different range of outcomes for the resettlers. In both localities of the settlement in Saguling case, government offiers are considered helpful in linking the social capital of resettlers.

Table 11a. Friendliness and helpfulness of government officers to the resettlers

\begin{tabular}{lll}
\hline \multirow{2}{*}{ Attitude } & No. of respondents & \\
\cline { 2 - 3 } & Vicinity of reservoir & Peri-urban area \\
\hline Friendly & 7 & 2 \\
\hline Friendly and Helpful & 6 & 7 \\
\hline Less Friendly/helpful & 4 & 0 \\
\hline Others & 1 & 2 \\
\hline None & 0 & 0 \\
\hline Total respondent & 18 & 11 \\
\hline
\end{tabular}

Table 11b. Assistance given to the resettlers by government officers

\begin{tabular}{lll}
\hline \multirow{2}{*}{ Type of assistance } & No. of respondent & \\
\cline { 2 - 3 } & Vicinity of reservoir & Peri-urban area \\
\hline Civil document/residential card & 10 & 7 \\
\hline Living place & 0 & 0 \\
\hline Economy & 2 & 0 \\
\hline Others & 2 & 0 \\
\hline None & 4 & 4 \\
\hline Total respondent & 18 & 11 \\
\hline
\end{tabular}

Cheung and Phillimore (2013) state that social integration is multi-dimensional and while not a linear process, does occur over time. The applicability of the concept of social capital and its correlation with the dimensions of poverty has been used to evaluate adaptation and integration of involuntary displaced people into their new social environment. As the resettlers enter into sociographic localities, different cultural or institutional setting can disrupt the stock of social capital (Quetulio-Navarra et al., 2014; Thompson et al., 2013). The social integration process of displaced people is context specific and somehow obscure 
the boundaries between the different dimensions of social capital (Quetulio-Navara et al., 2013). In the case of Saguling project, we reckoned that there was no significant issue in the aspect of social bridge and social link in the new environment, hence on social integration. The resettlers were welcomed, and they could join easily the agendas of the host community. The hosting community's concern, care and help to new comers is an important "bonding" social capital which is important in the recovery of jobs, income, and livelihood in general. In the case of urban resettlers in Saguling project, weaker social bond in the peri-urban area appeared to have affected the process of the livelihood re-establishment.

\section{Conclusion}

The study on the resettlement program related to Saguling development project has provided evidences that:

1) Hardship faced by the displaced people in rehabilitating their livelihood following large projects and resettlement programs may last for a long period of time. Changes or lost of occupation, lost of resources, or insufficient cash compensation has posed challenges in livelihood re-establishment.

2) The process of livelihood rehabilitation may take a long period of time, and education seems to be one of the most important pillars for the purpose. In particular, better education of the second generation can contribute to the improvement of family livelihood.

3) Social capital is obviously vital to livelihood reconstruction, and while sociographic localities are believed to determine the success of resettlement, peri-urban social environment in Saguling project has a negative corelation with livelihood of the resettlement.

\section{Acknowledgements}

This work was supported by JSPS KAKENHI Grant Numbers JP16H03320. The authors would like also to thank Syahras Fathin for the map preparation.

\section{References}

Adger, W. N., Dessai, S., Goulden, M., Hulme, M., Lorenzoni, I., Nelson, D. R., Naess, L. O., Wolf, J., \& Wreford, A. (2009). Are there social limits to adaptation to climate change? Climate Change, 93, 335-354. https://doi.org/10.1007/s10584-008-9520-z

Ager, A., \& Strang, A. (2008) Understanding Integration: A Conceptual Framework. Journal of Refugee Studies, 21(2), 166-191. https://doi.org/10.1093/jrs/fen016

Agnes, R. D., Solle, M. S., Said, A., \& Fujikura, R. (2009). Effects of Construction of the Bili-Bili Dam (Indonesia) on Living Conditions of Former Residents and Their Patterns of Resettlement and Return. International Journal of Water Resources Development, 25(3), 467-477. https://doi.org/10.1080/07900620902965186

Biswas, A. K., \& Tortajada, C. (2001). Development and Large Dams: A Global Perspective. 
Water Resources Development, 17(1), 9-21. https://doi.org/10.1080/07900620120025024

Cernea, M. M. (2008). Compensation and benefit sharing: Why resettlement policies and practices must be reformed. Water Science and Engineering, 1(1), 89-120. https://doi.org/10.1016/S1674-2370(15)30021-1

Cernea, M. M., \& Schmidt-Soltau, K. (2006). Poverty risks and national parks: policy issues in conservation and resettlement. World Development, 34(10), 1808-1830. https://doi.org/10.1016/j.worlddev.2006.02.008

Cheung, S., \& Phillimore, J. (2013). Social networks, social capital and refugee integration. Report for Nuffield Foundation, London.

Department of Mines and Energy. (1985). Saguling - Environmental Aspects. Department of Mines and Energy, Jakarta, Indonesia.

Development Assistance Committee. (1992). Guidelines for aid agencies on involuntary displacement and resettlement in development projects (Guidelines on Aid and Environment, No. 3). OECD, Paris.

Fujikura, R., \& Nakayama, M. (2012). The long-term impacts of resettlemet programmes resulting from dam construction projects in Indonesia, Japan, Laos, Sri Langka and Turkey: a comparison af land-for-land and cash compensation. International Journal of Water Resources Development, 29, 4-13. https://doi.org/10.1080/07900627.2012.741032

Gunawan, B. (1992). Floating Net Cage Culture - A Study of of People Involvement in the Fishing System of Saguling Dam,West Java (Masters thesis, Graduate School Ateneo de Manila University, Manila, Phillipines).

Hang Bhui, T. M., Schreinemachers, P., \& Berger, T. (2013). Hydropower development in Vietnam: Involuntary resettlement and factors enabling rehabilitation. Land Use Policy, 31, 536-544. https://doi.org/10.1016/j.landusepol.2012.08.015

IOE. (1985a). Environmental Impact Analysis of the Saguling Dam. Institute of Ecology, Bandung, West Java, Indonesia.

IOE. (1985b). Saguling Hydroelectric Power Plant, paper presented at Workshop on the Evaluation of Environmental Impact Assessment Applications in ASEAN countries, 4-7 March, Bandung, Indonesia.

Kaika, M. (2006). Dams as symbols of modernization: the urbanization of nature between geographical imagination and materiality. Annals of the Association of American Geographers, 96(2), 276-301. https://doi.org/10.1111/j.1467-8306.2006.00478.x

Kura, Y., Joffre, O., Laplante, B., \& Sengvilaykham, B. (2017). Coping with resettlement: A livelihood adaptation analysis in the Mekong River basin. Land Use Policy, 60, 139-149. https://doi.org/10.1016/j.landusepol.2016.10.017

Nakayama, M .(1998). Post-project review of Environmental Impact Assessment for Saguling Dam for involuntary resettlement. International journal of water resources development, 
14(2), 217-229. https://doi.org/10.1080/07900629849411

Nakayama, M., Yoshida, T., \& Gunawan, B. (1999). Compensation Schemes for Resettlers in Indonesian Dam Construction Projects. Water International, 24(4), 348-355. https://doi.org/10.1080/02508069908692187

Osbahr, H., Twyman, C., Adger, W. N., \& Thomas, D. S. G. (2010). Evaluating successful livelihood adaptation to climate variability and change in southern Africa. Ecology and Society, 15(2), 27.

PLN (Perusahaan Listrik Negara). (1989). Rencana pengelolaan dan pemantauan lingkungan (RKL\&RPL) PLTA Saguling (Planning for environmental management and monitoring of Saguling hydroelectric power). Jakarta. Indonesia.

Quetulio-Navarra, M., Niehof, A., \& van der Vaart, W. (2013) Social capital in involuntary displacement and resettlement. Intenational Journal of Social Science and Humanity Studies, $5(2), 139-154$.

Quetulio-Navarra, M., Niehof, A., Van der Horst, H., \& van der Vaart, W. (2014). Short-term risk experience of involuntary resettled households in the Philippines and Indonesia. Habitat International, 41, 165-175. https://doi.org/10.1016\%2Fj.habitatint.2013.07.013

Sayatham, M., \& Suhardiman, D. (2015). Hydropower resettlement and livelihood adaptation: The Nam Mang 3 project in Laos. Water resources and rural development, 5, 17-30. https://doi.org/10/1016/j.wrr.2015.01.001

Siciliano, G., Urban, F., Kimb, S., \& Lonn, P. D. (2015). Hydropower, social priorities and the rural - urban development divide : The case of large dams in Cambodia. Energy Policy, 86, 273-285. https://doi.org/10.1016/j.enpol.2015.07.009

Singer, J., \& Watanabe, T. (2014). Reducing reservoir impacts and improving outcomes for damforced resettlement: experiences in central Vietnam. Lakes \& Reservoirs: Research \& Management, 19(3), 225-235. https://doi.org/10.1111/1re.12072

Sisinggih, D., Wahyuni, S., \& Juwono, P. T. (2013). The resettlement programme of the Wonorejo Dam project in Tulungagung, Indonesia: the perceptions of former residents. International Journal of Water Resources Development, 29(1), 14-24. https://doi.org/10.1080/07900627.2012.743432

Sunardi, Gunawan, B., Manatunge, J., \& Pratiwi, F. D. (2013). Livelihood status of resettlers affected by the Saguling Dam project, 25 years afer inundation. International Journal of Water Resources Development, 29, 25-34. https://doi.org/10.1080/07900627.2012.738593.

Suwartapradja, O. S., Arifin, T., Kanum, A., Ansor, \& Djumari. (1985). Pemantauan sosial ekonomi budaya penduduk pindahan dari bawah ke atas genangan PLTA Saguling (Monitoring on socio-economic and cultural aspects of the displaced people in Saguling Area). Bandung, Indonesia: Pusat Penelitian Sumber Daya Alam dan Lingkungan, Universitas Padjadjaran. Indonesia. 


\section{Macrothink}

Journal of Asian Development

ISSN 2377-9594 2019, Vol. 5, No. 1

Thompson, S. K., Bucerius, S. M., \& Luguya, M. (2013). Unintended consequences of neighbourhood restructuring. British Journal of Criminology, 53(5), 924-941. https://doi.org/10.1093/bjc/azt032

Tilt, B., \& Gerkey, D. (2016). Dams and population displacement on China's Upper Mekong River: Implications for social capital and social-ecological resilience. Global Environmental Change, 36, 153-162. https://doi.org/10.1016/j.gloenvcha.2015.11.008

Wang, P., Wolf, S. A., Lassoie, J. P., \& Dong, S. (2013). Compensation policy for displacement caused by dam construction in China: An institutional analysis. Geoforum, 48, 1-9. https://doi.org/10.1016\%2Fj.geoforum.2013.04.009

Webber, M., \& McDonald, B. (2004). Involuntary resettlement, production and income: Evidence from the Xiaolangdi, PRC. World Development, 32(4), 673-690. https://doi.org/10.1016/j.worlddev.2003.10.010

Wilmsen, B. (2016) After the deluge: A longitudinal study of resettlement at the Three Gorged Dam, China. World Development, 84, 41-54. https://doi.org/10.1016/j.worlddev.2016.04.003

Wilmsen, B., \& Webber, M. (2015). What can we learn from the practice of development-forced displacement and resettlement for organised resettlements in response to climate change? Geoforum, 58, 76-85. https://doi.org/10.1016\%2Fj.geoforum.2014.10.016

Woolcock, M., \& Narayan, D. (2000). Social Capital: Implications for Development Theory, Research, and Policy. The World Bank Research Observer, 15(2), 225-249. https://doi.org/10.1093/wbro/15.2.225

World Bank. (2004). Involuntary ressettlement sourcebook: Planning and implementation in development projects. Washington, DC: World Bank.

World Energy Council. (2017). Energy resources - hydropower. Retrieved January 5, 2018 from https://www.worldenergy.org/data/resources/resource/hydropower

Yoshida, H., Agnes, R. D., Solle, M., \& Jayadi, M. (2013). A long-term evaluation of families affected by the Bili-Bili Dam development resettlement project in South Sulawesi, Indonesia. International Journal of Water Resources Development, 29(1), 50-58. https://doi.org/10.1080/07900627.2012.738495

\section{Copyright Disclaimer}

Copyright for this article is retained by the author(s), with first publication rights granted to the journal.

This is an open-access article distributed under the terms and conditions of the Creative Commons Attribution license (http://creativecommons.org/licenses/by/4.0/). 